\title{
Pertimbangan Diskresi Kepolisian Dalam Penanganan Kasus Tindak Pidana Minuman Keras Di Yogyakarta
}

\author{
Erda Aldo Amiarso \\ Program Studi Hukum, Fakultas Hukum, Universitas Muhammadiyah Yogyakarta \\ Korespondensi : erdaaldo19@gmail.com
}

\section{Info Artikel \\ Riwayat: \\ Diajukan : 22 Januari 2021 \\ Ditelaah : 21 Februari 2021 \\ Direvisi : 23 Februari 2021 \\ Diterima : 08 Maret 2021}

Kata Kunci :

kewenangan diskresi ; minuman keras ilegal ; penyidik

DOI:

10.18196/ijclc.v2i1.11562

\begin{abstract}
Abstrak
Pengaruh minuman keras ilegal dapat berdampak mengganggu ketertiban umum dan terjadinya kriminalitas. Polisi sebagai salah satu aparat penegak hukum memiliki peran untuk memelihara ketertiban masyarakat. Salah satu yang dapat dilakukan oleh Polisi dalam penanganan tindak pidana minuman keras adalah melakukan diskresi demi terjaminnya penegakan hukum. Berdasarkan hal tersebut penulis ingin mengkaji lebih lanjut tentang pertimbangan diskresi kepolisian dalam menangani kasus tindak pidana minuman keras di Yogyakarta. Tujuan penelitian ini untuk mengetahui bagaimana mekanisme pelaksanaan diskresi oleh Polresta Yogyakarta dalam penanganan kasus peredaran miras ilegal di Kota Yogyakarta. Metode penelitian yang digunakan dalam tulisan ini adalah penelitian hukum normatif dengan pendekatan perundangan-undangan. Pengumpulan data melalui studi pustaka, dan wawancara serta analisis data secara deskriptif dan kualitatif. Hasil penelitian mengenai kewenangan diskresi oleh penyidik dalam penanganan kasus peredaran minuman keras ilegal di wilayah hukum Polresta Yogyakarta bahwa Pelaksanaan diskresi oleh penyidik diberikan secara utuh kepada penyidik menurut penilaiannya sendiri dengan mempertimbangkan kepentingan umum dan menjunjung tinggi hak asasi manusia. Diskresi bersifat subyektif dan situasional tergantung pada kasusnya itu sendiri, dapat mempersingkat waktu atau tidak. Kepolisian menggunakan kewenangannya untuk melakukan tindakan diskresi khususnya dalam kasus peredaran minuman keras dimana pelaku dikenakan proses pembinaan serta menulis surat pernyataan agar tidak mengulangi lagi dan penyitaan barang bukti.
\end{abstract}

\section{Pendahuluan}

Negara Indonesia adalah negara hukum. Peran hukum sangatlah vital guna mengatur kepentingan antar manusia dalam bermasyarakat. Hukum merupakan cerminan dari suatu peradaban sehingga hukum tidak dapat lepas dari kehidupan manusia dan kepentingannya. ${ }^{1}$ Pembangunan nasional di bidang hukum sangat diperlukan guna mewujudkan visi Pembangunan Hukum Nasional. Visi tersebut berfungsi agar terwujudnya negara hukum yang adil dan demokratis melalui pembangunan sistem hukum nasional yang mengabdi kepada kepentingan rakyat dan bangsa di dalam bingkai Negara Kesatuan Republik Indonesia, untuk melindungi segenap bangsa Indonesia, serta seluruh tumpah darah Indonesia, memajukan kesejahteraan umum, mencerdaskan kehidupan bangsa dan ikut melaksanakan ketertiban dunia yang berdasarkan kemerdekaan, perdamaian abadi dan keadilan sosial berdasarkan Pancasila dan Undang-undang Dasar. ${ }^{2}$

Polisi Republik Indonesia / POLRI sebagai penegak hukum memiliki fungsi dalam pemerintahan negara. Fungsi Kepolisian dalam pemerintahan negara berfokus pada bidang pemeliharaan keamanan

\footnotetext{
${ }^{1}$ Bakhri, Syaiful. (2010). Kebijakan Kriminal dalam Perspektif Pembaruan Sistem Peradilan Pidana Indonesia. Yogyakarta: Total Media. h. 6

${ }^{2}$ Syamsuddin, Azis. (2011). Tindak Pidana Khusus. Jakarta: Sinar Grafika. h. 1
} 
dan ketertiban masyarakat, penegakan hukum, perlindungan, pengayoman, dan pelayanan kepada masyarakat. Aparat penegak hukum dalam melaksanakan kewajibannya harus sesuai dengan peraturan perundang-undangan yang ada. Salah satunya adalah penggunaan wewenang diskresi yang tidak dapat dilepaskan dari pelaksanaan penegakan hukum dan ketertiban masyarakat. ${ }^{3}$

Keberadaan institusi Polri pada awal berdirinya didasari oleh kebutuhan masyarakat akan ketertiban, keamanan dan kedamaian ditengah kehidupan masyarakat. Hal ini kemudian mengalami perluasan di mana keberadaan Institusi Polri menjadi alat negara dan berada pada posisi terdepan dalam sistem peradilan pidana di Indonesia. Etika profesi Kepolisian merupakan kristalisasi nilai-nilai yang dilandasi dan dijiwai oleh Pancasila serta mencerminkan jati diri setiap anggota Kepolisian Negara Republik Indonesia dalam wujud komitmen moral, selanjutnya disusun kedalam Kode Etik Profesi Kepolisian Negara Republik Indonesia.

Ketentuan yang berkaitan dengan Kode Etik Profesi Kepolisian Negara Republik Indonesia, sesuai dengan amanat Undang-undang No. 2 Tahun 2002 pada Pasal 34 dan 35 kemudian di wujudkan melalui Peraturan Kapolri No. 14 Tahun 2011 Tentang Kode Etik Profesi Kepolisian Negara Republik Indonesia. Kode etik ini merupakan pedoman perilaku dan moral bagi anggota Polri sebagai upaya pemulihan terhadap profesi Kepolisian, yang berfungsi sebagai pembimbing pengabdian, pelayanan, pembinaan, perlindungan, pengayoman, pencegahan dan penindakan terhadap suatu tindak pidana dan penyalahgunaan wewenang dalam kehidupan berkeluarga, bermasyarakat, berbangsa dan bernegara.

Tugas pokok yang diemban oleh institusi Polri adalah sebagaimana yang telah diatur dalam Pasal 13 UU No. 2 Tahun 2002, yaitu :

1. Memelihara keamanan dan ketertiban masyarakat

2. Menegakkan hukum; dan

3. Memberikan perlindungan, pengayoman, dan pelayanan kepada masyarakat

Ketiga tugas pokok tersebut tidak bersifat hirarki melainkan memiliki posisi yang sama pentingnya. Substansi tugas Polri untuk memelihara keamanan dan ketertiban bersumber dari kewajiban Polri untuk menjamin keamanan umum. Substansi tugas pokok untuk menegakkan hukum bersumber dari ketentuan peraturan perundang-undangan yang memuat tugas Polri dalam kaitannya dengan peradilan pidana. ${ }^{4}$

Tugas Polri memberikan perlindungan, pengayoman dan pelayanan kepada masyarakat bersumber dari kedudukan dan fungsi kepolisian sebagai bagian dari fungsi pemerintahan negara yang pada hakekatnya bersifat pelayanan publik (public service) yang termasuk kewajiban umum kepolisian. Diskresi merupakan salah satu wewenang Polisi dalam menjalankan fungsinya. Istilah diskresi dikenal dalam Black Law Dictionary yang berasal dari bahasa Belanda "Discretionair" yang berarti kebijaksanaan dalam halnya memutuskan sesuatu tindakan berdasarkan ketentuan-ketentuan peraturan undangundangan atau hukum yang berlaku tetapi atas dasar kebijaksanaan, pertimbangan atau keadilan. ${ }^{5}$

Polisi memerlukan wewenang dan wewenang ini merupakan tindakan-tindakan kepolisian yang didasarkan hak asasi, seperti memanggil, memeriksa, menggeledah, menangkap dengan cara-cara dan tindakan-tindakan lain yang diizinkan oleh undang-undang, tetapi pelaksanaannya diserahkan kepada Polisi untuk menentukan dengan batasan-batasan tertentu. ${ }^{6}$ Penggunaan kewenangan diskresi sebenarnya diberikan kepada anggota kepolisian guna menghadapi suatu kasus yang apabila diproses melalui tahapan-tahapan yang sesuai dengan peraturan perundang-undangan yang berlaku justru dapat menyebabkan menumpuknya perkara, macet, tidak efisien, boros dan atau kurang ada manfaatnya. ${ }^{7}$

\footnotetext{
${ }^{3}$ Faal, M. (1991). Penyaringan Perkara Pidana Oleh Polisi (Diskresi Kepolisian). Jakarta: PT Pradnya Paramita. h. 121

${ }^{4}$ Rahardi, Pudi. (2007). Hukum Kepolisian : Profesionalisme dan Reformasi Polri. Surabaya: Laksbang Mediatama. h. 68

${ }^{5}$ Puspa, Yan Pramadya. (1991). Kamus Hukum : Bahasa Belanda, Indonesia, Inggris. Semarang: Aneka. h. 91

${ }^{6}$ Faal, M. Op.Cit. h. 123

${ }^{7}$ Ibid.
} 
Dalam rangka pertanggungjawaban yang independen, polisi bebas mengambil diskresi meskipun hal itu mendatangkan konsekuensi dramatik terhadap masyarakat. ${ }^{8}$

Kepolisian berdasarkan Undang-Undang Nomor 8 Tahun 1981 tentang Kitab Undang-Undang Hukum Acara Pidana (KUHAP) diberikan kewenangan dan tanggung jawab untuk melakukan penyidikan. Kepolisian merupakan ujung tombak fungsionalisasi hukum pidana, karena pihak kepolisian yang pertama kali berhadapan secara langsung dengan suatu tindak pidana tertentu yang terjadi serta yang pertama kali menilai layak atau tidaknya suatu kasus atau peristiwa untuk diajukan ke pengadilan. ${ }^{9}$ Manfaat diskresi dalam penanganan tindak pidana atau kejahatan adalah sebagai salah satu cara untuk membangun moral petugas kepolisian dan meningkatkan profesionalitas dan intelektualitas anggota polisi dalam menjalankan tugas dan wewenangnya secara proporsional dan memenuhi rasa keadilan, bukan atas dasar kesewenang-wenangan. ${ }^{10}$ Bedasarkan itulah wewenang diskresi diberikan kepada Kepolisian Negara Republik Indonesia.

Banyaknya permasalahan yang didapat dari dampak negatif pada era milenial ini generasigenerasi muda Indonesia sangat riskan terpengaruh budaya asing dan peniruan gaya hidup barat yang semakin merasuki generasi-generasi muda Indonesia khususnya di Kota Yogyakarta. Salah satu masalah yang sangat memprihatinkan dan harus mendapatkan perhatian serius dari pemerintah maupun penegak hukum ialah masalah penyalahgunaan minuman keras ilegal (oplosan). Tidak jarang dari penyalahgunaan tersebut memicu lahirnya kejahatan yang sangat meresahkan masyarakat dan menganggu ketertiban umum seperti penganiayaan, pemerkosaan, pencurian, dan lain sebagainya yang disebabkan karena pengaruh minuman keras ilegal (oplosan). Penggunaan minuman keras oplosan ini dapat menjadikan penyebab tindakan kriminal dikehidupan masyarakat, karena perubahan perilaku seseorang misal perkelahian, tawuran, dan tindakan kekerasan lainnya, gangguan fungsi sosial dan pekerjaan, gejala fisikologis, gejala sikoligis misal perubahan alam perasaan, mudah marah, cepat emosi, gampang tersinggung, ngelantur, gangguan konsentrasi. ${ }^{11}$

Polri mempunyai tugas menjaga keamanan dan ketertiban masyarakat di Indonesia. Dalam menjaga ketertiban tersebut Polri berperan penting dalam menanggulangi penyakit masyarakat. Salah satu penyakit masyarakat adalah minuman keras. Miras ini adalah sebuah fenomena yang membuat resah masyarakat dan merupakan sebuah masalah publik yang bertentangan dengan nilai dan norma yang berlaku di masyarakat. Polri sebagai bagian dari pranata sosial bertugas menjaga agar tingkah laku masyarakat selalu sesuai dengan nilai dan norma yang berlaku, maka sudah merupakan kewajiban Polri untuk mengambil langkah yang sistematis dan terstruktur untuk menanggulangi permasalahan kebiasaan miras ini. ${ }^{12}$

Tidak sedikit kasus yang menunjukkan akibat dari masalah penggunaan minuman keras oplosan ini banyak membawa dampak yang merugikan baik diri sendiri maupun orang lain. Seperti contoh kasus berikut ini, dua penjual minuman keras (miras) jenis ciu diamankan oleh Satreskrim Polresta Kota Yogyakarta. Kanit IV Satreskrim Polresta Yogyakarta Iptu Basungkowo mengatakan, kedua penjual ciu itu berinisial KV, warga Kabupaten Bantul dan MM, warga Kota Yogyakarta. Penangkapan keduanya dilatarbelakangi kasus kematian enam warga Kota Yogyakarta usai menenggak miras oplosan. Tiga korban di daerah Pakualaman dan tiga korban di Tegalrejo diketahui mengonsumsi ciu yang dijual oleh MM. Ciu yang dijual oleh MM ini didapatnya dari KV. Sedangkan KV membelinya dari seseorang di daerah Bekonang Jawa Tengah dan dikemas ke dalam botol berukuran $500 \mathrm{ml}$ yang dijual KV ke MM seharga Rp

\footnotetext{
8 Harahap, M.Yahya. (2016). Pembahasan Permasalahan Dan Penerapan KUHAP Penyidikan Dan Penuntutan. Jakarta: Sinar grafika. h. 93

${ }^{9}$ Fachmi. (2011). Kepastian Hukum Mengenai Putusan Batal Demi Hukum dalam Sistem Peradilan Pidana Indonesia. Jakarta: PT. Ghalia Indonesia Publishing. h. 58

${ }^{10}$ Abdussalam, H.R. (2009). Hukum Kepolisian Sebagai Hukum Positif dalam Disiplin Hukum. Jakarta: Restu Agung. h. 20

${ }^{11}$ Hawari, Dadang. (2005). Terapi dan Rehabilitasi Muthakhir Pasien NAZA. Jakarta: Fakultas Kedokteran Universitas Indonesia. h. 40.

${ }^{12}$ Rohadi \& Kusriyah, Sri. (2017). Peran Polisi Masyarakat (POLMAS) Dalam Menangani Perbuatan Akibat Minman Keras Di Wilayah hukum Polres. Jurnal Hukum Khaira Ummah, 12(3). h. 655
} 
13 ribu. MM membeli dari $\mathrm{KV}$ satu kardus yang berisi 20 botol $500 \mathrm{ml}$ dan dijual lagi seharga $\mathrm{Rp}$. $20.000,00.13$

Kasus penyalahgunaan minuman keras lainnya terungkap, sebanyak 2690 botol minuman keras (miras) diamankan oleh jajaran Polresta Kota Yogyakarta dari penjual miras di daerah Sleman. Terungkapnya penjualan miras ini berawal dari patroli yang dilakukan oleh anggota Sabhara Polresta Yogyakarta pada Sabtu tanggal 3 Agustus 2019. Kapolresta Yogyakarta, Kombes Pol Armaini mengatakan salah satu anggota Polresta Yogyakarta mencurigai seorang remaja berinisial AS usia 19 Tahun. Saat itu, AS tengah membawa sebotol miras berjenis Whiskey di sebuah burjo di daerah Kecamatan Umbulharjo, Kota Yogyakarta. Polisi kemudian meminta keterangan AS terkait miras yang dibawa dan dikonsumsinya. Dari pengakuan AS, diketahui miras itu dibeli dari sebuah warung di daerah Gejayan, Kabupaten Sleman. Polresta Kota Yogyakarta melakukan lidik di sebuah tempat ruko tanpa nama kemudian melakukan pengecekan dan penggeledahan terhadap penanggung jawab tempat tersebut. Ruko yang digunakan untuk tempat tinggal dan menjual minuman ini menjual ribuan miras berbagai merek. Atas kepemilikan minuman keras tersebut, Polisi mengamankan pemilik ruko berinisial AEH berusia 44 tahun. Polisi juga berhasil menyita 2690 botol miras berbagai jenis didalam ruko tersebut. ${ }^{14}$

Penyidik dalam kasus ini telah melakukan kewenangan diskresi dengan upaya pemaksaan pengakuan terhadap remaja tersebut. Upaya pemaksaan tersebut bertujuan agar remaja tersebut memberikan keterangan sebenarnya kepada penyidik. Sebenarnya tindakan diskresi dalam bentuk upaya paksa seperti yang dilakukan oleh Penyidik tidaklah jelas, sehingga banyak masyarakat yang berasumsi bahwa upaya paksa yang digunakan penyidik sebagai bentuk diskresinya guna mendapatkan pengakuan dan keterangan dari pelaku suatu tindak pidana yaitu dengan cara kekerasan. Berdasarkan permasalahan tersebut, penting untuk membahas kewenangan diskresi kepolisian apa saja yang menjadi pertimbangan diskresi penyidik kepolisian. Sehingga penelitian ini bertujuan agar masyarakat dapat memahami benar bahwa Kepolisian termasuk penyidik mempunyai suatu kewenangan besar/luas dalam pelaksanaan penyidikan, dimana bentuk kewenangan tersebut adalah diskresi yang dapat digunakan dalam pelaksanaan tugas pemolisian serta penyidikan.

\section{Metode Penelitian}

Metode penelitian yang digunakan adalah penelitian hukum normatif, yaitu penelitian dengan suatu pendekatan masalah dengan cara mengkaji suatu peraturan perundang-undangan yang berlaku dan berkompeten untuk digunakan sebagai dasar dalam melakukan pemecahan masalah. Penelitian ini menggunakan data sekunder yang terdiri dari bahan hukum primer berupa peraturan perundangundangan terkait, bahan hukum sekunder berupa buku-buku, artikel ilmiah dan bahan hukum tersier berupa. Metode pengumpulan data yang digunakan dalam penelitian ini ialah studi pustaka dan interview atau wawancara bersama narasumber. Analisis data dalam penelitian ini dilakukan secara deskriptif kualitatif yaitu mengelompokkan data dan menyeleksi data yang diperoleh dari hasil penelitian dengan bertitik pada permasalahan yang kemudian hasilnya disusun secara sistematik dan disusun dan merupakan satu data yang kongkrit

\footnotetext{
${ }^{13}$ Edi, Purnomo. (2019). 2 Penjual Ciu Di Yogya Ditangkap Usai 6 Orang Tewas Gara-Gara Miras Oplosan. Diakses pada tanggal 16 Februari 2020, https://www.merdeka.com/peristiwa/2-penjual-ciu-di-yogya-ditangkapusai-6-orang-tewas-gara-gara-miras-plosan.html,

${ }^{14}$ Edi, Purnomo. (2019). Gerebek Sebuah Ruko Di Yogyakarta, Polisi Amankan 2690 Botol Miras Ilegal. Diakses pada tanggal 16 Februari 2020, https://www.merdeka.com/peristiwa/gerebek-sebuah-ruko-diyogyakarta-polisi-amankan-2690-botol-miras-ilegal.html,
} 


\section{Hasil dan Pembahasan}

\section{A. Pertimbangan Penyidik Polresta Yogyakarta dalam Menjalankan Kewenangan Diskresi dalam Penanganan Kasus Peredaran Minuman Keras Ilegal di Kota Yogyakarta}

Berdasarkan informasi yang beredar di media sosial beberapa waktu belakangan ini menunjukkan maraknya penjualan minuman keras ilegal (oplosan) atau tidak berizin. Penyalahgunaan minuman keras ilegal (oplosan) memberikan efek buruk bagi perilaku seseorang. Adapun pengadaan minuman keras diatur dalam sejumlah peraturan sebagai berikut :

1. Kitab Undang-Undang Hukum Pidana :

a. Pasal 300 ayat (1) KUHP, berbunyi: "Dengan hukuman penjara selama-lamanya satu tahun atau denda sebanyak-banyaknya Rp. 4.500, dihukum: Barang siapa dengan sengaja menjual atau menyuruh minum-minuman yang memabukkan kepada seseorang yang telah kelihatan nyata mabuk; Barang siapa dengan sengaja membuat mabuk seorang anak yang umurnya di bawah 16 tahun; dan Barang siapa dengan kekerasan atau ancaman kekerasan dengan sengaja memaksa orang akan minum minuman yang memabukkan".

b. Pasal 300 ayat (2) KUHP, berbunyi: "Kalau perbuatan itu menyebabkan luka berat pada tubuh, sitersalah dihukum penjara selama - lamanya tujuh tahun".

c. Pasal 300 ayat (3) KUHP, berbunyi: "Kalau perbuatan itu menyebabkan orang mati, si tersalah dihukum penjara selama - lamanya sembilan tahun".

2. Peraturan Daerah Istimewa Yogyakarta Nomor 12 Tahun 2015 Tentang Pengendalian Pengawasan Minuman Beralkohol serta Pelarangan Minuman Oplosan :

a. Pasal 51 : "Setiap orang yang mengedarkan Minuman Beralkohol di tempat yang dilarang sebagaimana dimaksud dalam Pasal 24 ayat (1), dipidana dengan pidana kurungan paling lama 6 (enam) bulan atau denda paling banyak Rp. 50.000.000,- (lima puluh juta rupiah)".

b. Pasal 52 : “Produsen Minuman Beralkohol Tradisional yang tidak mempunyai izin sebagaimana dimaksud dalam Pasal 25 huruf a, dipidana dengan pidana kurungan paling lama 6 (enam) bulan atau denda paling banyak Rp 50.000.000,- (lima puluh juta rupiah)".

c. Pasal 53 : “ (1) Setiap orang yang menjual secara langsung Minuman Beralkohol golongan A, golongan B dan Golongan C, selain dari tempat sebagaimana diatur dalam Pasal 27, dipidana dengan pidana kurungan paling lama 6 (enam) bulan atau denda paling banyak $\mathrm{Rp}$ $50.000 .000,00$ (lima puluh juta rupiah). (2) Setiap orang yang meminum Minuman Beralkohol di kamar hotel melebihi ketentuan sebagaimana dimaksud dalam Pasal 28, dipidana dengan pidana kurungan paling lama 1 (satu) bulan atau denda paling banyak Rp 5.000.000,00 (lima juta rupiah)".

d. Pasal 54 : "Pengecer dan Penjual Langsung yang menjual Minuman Beralkohol kepada konsumen berusia kurang dari 21 (dua puluh satu) tahun sebagaimana dimaksud dalam Pasal 30 ayat (1) dipidana dengan pidana kurungan paling lama 6 (enam) bulan atau denda paling banyak Rp 50.000.000,00 (lima puluh juta rupiah)".

3. Peraturan Daerah Kota Yogyakarta Tentang Izin Penjualan dan Pemungutan pajak atas izin menjual minuman keras dalam Peraturan Daerah Kotapraja Yogyakarta Nomor 7 Tahun 1953 yakni berbunyi:

a. Pasal 22 (1) Barang siapa melanggar atau tidak menepati ketentuanketentuan tersebut dalam pasal 5 ayat (1) pasal 10,11,17, 18 ayat (1) sampai dengan ayat 5 pasal 20 ayat (1) dan

b. Pasal 22 ayat (1), dihukum denda sebanyak-banyaknya Rp. 5.000,- (lima ribu rupiah) atau dihukum kurungan selama-lamanya enam bulan. (2) Hukuman tersebut ayat (1) dapat disertai pensitaan minuman keras yang berhubungan dengan pelanggaran terhadap pasal 5 ayat (1), pasal 10, 11, 20 ayat (1) dan pasal 22 ayat (1). (3) Hukuman tersebut dalam ayat (1) dan (2) tidak mengurangi kewajiban membayar izin penjualan". 
Maraknya aksi kriminalitas yang terjadi disebabkan oleh penggunaan miras oplosan. Penyalahgunaan miras oplosan tersebut memiliki dampak yang buruk, banyak korban yang berjatuhan bahkan sampai meninggal dunia akibat miras oplosan ini. Bukan hanya itu miras juga digunakan untuk melakukan aksi klitih. Yogyakarta salah satu nya, akhir-akhir ini banyak terjadi klitih yang di awali dari aksi penyalahgunaan miras oplosan yang menimbulkan banyak korban berjatuhan akibat aksi klitih ini. Di ketahui bahwa kasus klitih dan penyalahgunaan miras oplosan dilakukan agar mereka semakin berani, tega, dan semakin percaya diri dalam melakukan aksinya.

Yogyakarta adalah kota yang cukup rawan akan peredaran minuman keras ilegal, hal itu disebabkan karena Yogyakarta selain dikenal sebagai kota Pendidikan, dikenal pula sebagai kota pariwisata. Prawirotaman merupakan salah satu wilayah di Yogyakarta yang dikenal sebagai tempat wisatawan asing berkumpul karena menyediakan minuman keras berbagai merek yang ditemukan hampir di semua caffe di Prawirotaman. Di Kota Yogyakarta sendiri jika ingin menjual miras beralkohol harus memiliki surat izin sesuai dengan Perda DIY No. 12 Tahun 2015 Tentang Pengendalian dan Pengawasan Minuman Beralkohol Serta Pelarangan Minuman Oplosan. Jika tidak memiliki izin akan di proses hukum, karena efek minuman keras menjadi latar belakang penyebab terjadinya kriminalitas dan mengganggu ketertiban umum.

Berdasarkan data dari Satuan Reserse Narkoba Polresta Yogyakarta Tahun 2018-2020 terdapat 7 kasus miras yang di diskresikan seperti yang tercantum di dalam tabel berikut ini:

Tabel 1. Rekapitulasi Putusan Mahkamah Konstitusi Republik Indonesia

\begin{tabular}{|c|c|c|c|c|c|c|c|}
\hline \multirow{3}{*}{ No } & \multirow{3}{*}{$\begin{array}{c}\text { Tahu } \\
\mathrm{n}\end{array}$} & \multirow{3}{*}{$\begin{array}{l}\text { Jumlah } \\
\text { Kasus }\end{array}$} & \multicolumn{3}{|c|}{ Tersangka } & Peran & \multirow{3}{*}{ Keterangan } \\
\hline & & & \multicolumn{2}{|c|}{ Jenis Kelamin } & \multirow[t]{2}{*}{ Umur } & \multirow{2}{*}{ Pengedar Miras } & \\
\hline & & & $\mathrm{L}$ & $P$ & & & \\
\hline 1 & 2018 & 4 & 4 & - & $29-51$ & 4 & \multirow{3}{*}{$\begin{array}{c}\text { Terhadap para pengedar dikenakan } \\
\text { proses pembinaan serta menulis } \\
\text { surat penyataan dan penyitaan } \\
\text { barang bukti }\end{array}$} \\
\hline 2 & 2019 & 2 & 2 & - & $29-32$ & 2 & \\
\hline 3 & 2020 & 1 & 1 & - & 21 & 1 & \\
\hline \multicolumn{2}{|c|}{ Jumlah } & 7 & 7 & - & & 7 & \\
\hline
\end{tabular}

Sumber: Satuan Reserse Narkoba Polresta Yogyakarta Tahun 2018-2020

Ada 7 kasus diskresi pada tabel tersebut. Pertama terjadi pada tahun 2018 dimana terdapat empat kasus pengedaran minuman keras ilegal/oplosan dengan empat orang pelaku (laki-laki) yang berumur 29 sampai 51 tahun. Terhadap kasus tersebut Kepolisian melakukan proses diskresi yang bertujuan untuk penyaringan perkara oleh kepolisian agar tidak menumpuknya suatu perkara. Diskresi dilakukan karena motif pelaku mengedarkan minuman keras illegal/oplosan demi kebutuhan hidup, kurangnya alat bukti, dan menjual minuman keras untuk dikonsumsi sebagai obat atau jamu saja. Meski demikian, terhadap perbuatan yang dilakukan, pelaku diberikan hukuman melalui proses pembinaan serta menulis surat pernyataan agar tidak mengulang lagi dan penyitaan barang bukti.

Kasus kedua terjadi di Tahun 2019, dimana terdapat dua kasus pengedaran minuman keras ilegal/oplosan dengan dua orang pelaku (laki-laki) yang berumur 29 tahun dan 32 tahun. Terhadap kasus tersebut Kepolisian melakukan proses diskresi yang di latar belakangi karena masalah ekonomi pelaku yang terpaksa menjual minuman keras. Alasan diskresi lainnya, karena pelaku menjual minuman keras pada saat bulan Ramadhan sekalipun sudah mendapat izin, namun dipandang tidak menghormati bulan Ramadhan. Terhadap perbuatan tersebut, pelaku dikenakan proses pembinaan serta menulis surat peryataan dan penyitaan barang bukti.

Kasus terakhir, terjadi di Tahun 2020, dimana terdapat satu kasus pengedaran minuman keras ilegal/oplosan dilakukan oleh pelaku (laki-laki) yang berumur 21 tahun. Terhadap kasus tersebut Kepolisian melakukan proses diskresi yang dilakukan karena diketahui pelaku masih di bawah umur. 
Terhadap perbuatan tersebut, pelaku dikenakan proses pembinaan serta menulis surat peryataan dan penyitaan barang bukti dan pemanggilan orangtua. ${ }^{15}$

Berdasarkan hasil wawancara bersama bapak Rudi Arto, pertimbangan penyidik dalam menjalankan kewenangan diskresi dalam penanganan kasus khususnya peredaran minuman keras yaitu sebagai berikut : 16

1. Denda terlalu ringan

2. Kebiasaan suku tertentu

3. Pelaku berusia di bawah umur / berusia lanjut

4. Faktor ekonomi

5. Barang bukti tidak lengkap

6. Untuk Pengobatan/jamu

7. Efisiensi waktu

8. Mencegah penumpukan perkara

Menurut penulis pertimbangan-pertimbangan yang digunakan untuk melaksanakan kewenangan seorang polisi saat di lapangan yaitu tergantung situasi dan kondisi, karena tidak semua kasus minuman keras di diskresikan. Jika menurut petugas di lapangan kasus tersebut tidak bisa di diskresikan karena sudah merugikan atau membahayakan orang lain maka tidak akan dilakukan diskresi. Beda jika terdapat kasus ketika pelaku sedang membawa minuman keras tetapi tidak di temukan tindak pidana yang di timbulkan maka dari itu demi kebaikan dan keadilan bisa saja kasus itu di diskresikan dan menyita barang bukti.

Menurut bapak Rudi Arto, akhir-akhir ini di Yogyakarta banyak terjadi klitih. Banyak korban yang berjatuhan akibat klitih ini yang disebabkan karena mengkonsumsi miras. Mengkonsumsi miras sendiri diyakini dapat membuat remaja semakin berani, tega, dan semakin percaya diri dalam melakukan aksinya. Meskipun tidak semua semua yang mengkonsumsi miras ini melakukan hal-hal yang negatif seperti berbuat onar dan berbuat rusuh di masyarakat, ada juga yang mengkonsumsi miras hanya untuk bersenang-senang. Tapi tetap apapun tujuannya, mengkonsumsi miras oplosan tetaplah dilarang oleh undang-undang dan agama, karena menimbulkan banyak dampak negatif, seperti kecanduan, merusak mental, merusak akal, merusak organ tubuh, dan bahkan sampai menyebabkan kematian bagi penggunanya.

Menurut Bapak Ahmat Djaeni, pada umumnya pelaksanaan diskresi tersebut dilakukan oleh semua aparat kepolisian sebagai pejabat publik. Akan tetapi ada klausa khusus dimana diskresi secara penuh dilakukan oleh aparat kepolisian yang secara khusus bertugas di lapangan karena petugas langsung berhadapan dan berinteraksi dengan masyarakat serta pelaku kejahatan yang sedang ditanganinya dalam mengemban tugas kepolisian sebagai penjaga ketertiban di masyarakat. ${ }^{17}$

Bapak Ahmat Djaeni menjelaskan peraturan perundang-undangan yang dijadikan dasar diskresi oleh penyidik yaitu :18

1. Undang-Undang Dasar Negara Republik Indonesia Tahun 1945

Tugas dan wewenang Kepolisian adalah suatu tindakan yang dilakukan oleh aparat Kepolisian sebagai pengayom, pelindung, dan pelayan masyarakat tidak dapat dilepaskan mengingat sifat penugasan yang diberikan sangat memerlukan wewenang. Setiap produk Undang-Undang mempunyai hirarki sendiri dalam susunan tata peraturan di Indonesia, fungsi dari UndangUndang Dasar 1945 mempunyai keterkaitan satu sama lain dengan undang-undang lainnya sebagai aturan dasar bagi Undang-Undang yang ada di bawahnya. Kewenangan diskresi penyidik Dalam kewenangan tersebut, seorang aparat penegak hukum yang dalam hal ini adalah Polisi mempunyai kewenangan yang sangat penuh dalam mengambil sikap serta tindakan untuk melakukan wewenang diskresi dalam menyaring perkara pidana yang dianggap ringan serta

\footnotetext{
${ }^{15}$ Wawacara dengan Rudy Arto Unit SATRESNARKOBA Polresta Yogyakarta, Tanggal 13 Maret 2020

16 Ibid,

17 Wawacara dengan AKP Ahmat Djaeni Ditreskrimsus Polda Daerah Istimewa Yogyakarta, Tanggal 27 Agustus 2020

${ }^{18}$ Ibid,
} 
tidak efektif bila diselesaikan melalui proses peradilan pidana, maka dari itu diskresi penyidik sangat berkaitan erat dengan keefektifan suatu perkara.

2. Undang-Undang Nomor 2 Tahun 2002 Tentang Kepolisian Negara Republik Indonesia

Menurut di dalam Pasal 18 Undang-Undang No. 2 Tahun 2002 Tentang Kepolisian Negara Republik Indonesia dijelaskan bahwa: Pasal 1 : Untuk kepentingan umum pejabat Kepolisian Negara Republik Indonesia dalam melaksanakan tugas dan wewenangnya dapat bertindak menurut penilaiannya sendiri.

Pasal 2 : Pelaksanaan ketentuan sebagimana dimaksud dalam ayat (1) hanya dapat dilakukan dalam keadaan yang sangat perlu dengan memperhatikan peraturan perundangundangan, serta Kode Etik Profesi Kepolisian Negara Republik Indonesia. Kalimat dalam Pasal 18 ayat (1) tersebut yang berbunyi "bertindak menurut penilaian sendiri" merujuk kepada konsep diskresi atau "Freies Ermessen". Dalam pasal itulah landasan hukum kewenangan anggota kepolisian untuk melakukan diskresi, Dalam bahasa Undang-Undang No. 2 Tahun 2002 tersebut diskresi dirumuskan sebagai "dalam keadaan yang sangat perlu". ${ }^{19}$

Penjelasan dari Bapak Ahmat Djaeni undang-undang tersebut berbunyi, yang dimaksud dengan bertindak menurut penilaiannya sendiri adalah "suatu tindakan yang dapat dilakukan oleh anggota Kepolisian Negara Republik Indonesia yang dalam bertindak harus mempertimbangkan manfaat serta resiko dari tindakannya dan betul-betul untuk kepentingan umum".

Dasar pelaksanaan diskresi dalam KUHAP terdapat dalam Pasal 7 ayat (1) huruf j dimana dijelaskan penyidik sebagaimana dimaksudkan dalam Pasal 6 ayat (1) huruf a karena kewajibannya mempunyai wewenang mengadakan penghentian penyidikan, akan tetapi tidak boleh dilakukan sembarangan karena di Pasal 7 ayat (1) huruf j juga menjelaskan mengadakan tindakan lain menurut hukum yang bertanggung jawab. Maka dari itu letak dari Pasal 7 ayat (1) huruf j KUHAP serta Pasal 16 ayat (1) huruf 1 serta Pasal 18 ayat (1) Undang-Undang Nomor 2 Tahun 2002 Tentang Kepolisian Negara Republik Indonesia merupakan suatu dasar pelaksanaan tindakan diskresi oleh Kepolisian dan sebagai dasar bekerjanya seorang aparat penegak hukum (legal formil) dalam menjembatani suatu bentuk penanganan perkara pidana yang dirasa ringan dan tidak efektif bila diproses melalui lembaga peradilan dengan melakukan tindakan lain menurut hukum yang bertanggung jawab demi kepentingan masyarakat yang lebih luas atau kepentingan umum

Menurut Penulis Pertimbangan polisi khususnya penyidik dalam hal menjalankan kewenangan diskresi dalam perkara kasus peredaran minuman keras ilegal/oplosan bersifat subyektif dan tergantung pada kasusnya itu sendiri, apakah dapat mempersingkat waktu atau tidak. Sekalipun diskresi penyidik bersifat subyektif dan situasional, namun diskresi juga ada dasar hukumnya, sehingga tidak sembarangan. Maka dari itu letak dari Pasal 7 ayat (1) huruf j KUHAP serta Pasal 16 ayat (1) huruf l serta Pasal 18 ayat (1) Undang-Undang Nomor 2 Tahun 2002 Tentang Kepolisian Negara Republik Indonesia merupakan suatu dasar pelaksanaan tindakan diskresi. Dalam hal ini seorang aparat penyidik dituntut harus penuh tanggung jawab dapat bertindak menurut penilaiannya sendiri sesuai wewenangnya menurut kepentingan umum.

Alasan para pelaku penyalahguna minuman keras yang di paparkan di atas adalah alasan yang melihat situasi dan kondisi maka dari itu kepolisian menggunakan kewenangannya untuk melakukan tindakan diskresi dengan menjatuhkan sanksi berupa proses pembinaan, menulis surat peryataan agar tidak mengulang lagi dan penyitaan barang bukti. Jika ada pengulangan kasus baru para pelaku akan di proses sebagai tindak pidana ringan dan di jatuhi denda. Penjelasan tersebut mempunyai makna dalam pelaksanaan tindakan diskresi polisi harus didasari pada aspek kepentingan umum dan melihat situasi dan kondisi. Meskipun tindakan tersebut dilakukan menurut penilaiannya sendiri, sehingga dalam pelaksanaan diskresi tersebut harus mempertimbangankan manfaat serta resiko yang timbul setelah tindakan tersebut sesuai dengan kewenangan dan jabatan seorang aparat Kepolisian dalam mengemban fungsi penyidikan dalam Proses Peradilan Pidana (Criminal Justice Process).

${ }^{19} \mathrm{Ibid}$ 


\section{B. Mekanisme Pelaksanaan Diskresi Oleh Polresta Yogyakarta dalam Penanganan Kasus Peredaran Minuman Keras ilegal di Kota Yogyakarta}

Mekanisme pelaksanaan diskresi tidak lepas dari pasal 7 KUHAP. Diatur dalam Undang-undang Nomor 8 tahun 1981 tentang Hukum Acara Pidana, penyidik sebagaimana diatur dalam pasal 6 ayat (1) huruf (a) karena kewajibannya mempunyai wewenang:

1. Menerima laporan atau pengaduan dari seseorang tentang adanya tindak pidana

2. Melakukan tindakan pertama pada saat ditempat kejadian

3. Menyuruh berhenti seorang tersangka dan memeriksa tanda pengenal diri tersangka

4. Melakukan penagkapan, penahanan, penggeledahan dan penyitaan

5. Melakukan pemeriksaan dan penyitaan surat

6. Mengambil sidik jari dan memotret seseorang

7. Memanggil orang untuk didengar dan diperiksa sebagai terduga

8. Mendatangkan saksi yang diperlukan dalam hubungannya dengan pemeriksaan perkara

9. Mengadakan penghentian penyidikan

10. Mengadakan tindakan lain menurut hukum yang bertanggungjawab.

Mengadakan tindakan lain menurut hukum yang bertanggung jawab dalam poin tersebutlah yang digunakan sebagai dasar diskresi bagi penyidik dalam menangani suatu perkara pidana. Dasar tersebut pelaksanaan tindakan diskresi dapat berlangsung secara sah menurut hukum. Diskresi memberikan kesempatan serta sebuah kebebasan bagi penegak hukum dalam membuat keputusan sesuai dengan rasa keadilan oleh pribadi seseorang yang mempunyai wewenang kekuasaan. Konteks pembahasannya lebih memperhatikan bagaimana seseorang petugas secara individu atau kelompok yang punya wewenang dalam menangani suatu kasus untuk menggunakan kebijakan sendiri dalam suatu situasi yang terjadi untuk melakukan atau tidak melakukan. Secara sederhana, diskresi menunjukan kebebasan kekuasaan untuk membuat keputusan dengan mempertimbangkan pribadi yang memperhatikan kebaikan dan keadilan semua pihak, guna mencari alternatif lain yang bukan pidana, dalam hal ini pidana merupakan ultimum remidium atau sebagai sarana terakhir.

Prakteknya pertimbangan atau pilihan diskresi banyak dipaksakan tidak hanya oleh aturan formal yang ada tapi juga oleh desakan ekonomi, sosial dan politik yang terjadi atas pilihan yang ada. Desakan-desakan tersebut menjadi alasan penyidik menetapkan kebijakan akan tetapi kebijakan yang di tetapkan tidak membuat pelanggaran atas norma-norma hukum lain atau hak-hak yang semestinya dipenuhi. Alasan tersebutlah yang menjadi salah satu hal penting yang sesuai dengan point-point dan pembuat kebijakan diskresi untuk membuat prosedur dan metode kerjanya juga.

Menurut Bapak Rudi Arta diskresi adalah penerapan suatu kebijaksanaan bertindak atas pertimbangan pribadi dan batasanya yaitu diskresi harus dilakukan hanya atas dasar pertimbangan kepentingan umum dan berikut mekanisme pelaksanaan diskresi dalam penanganan kasus peredaran minuman keras ilegal :20

Tabel 2 menjelaskan bahwa mekanisme diskresi kepolisian dalam penanganan kasus peredaran minuman keras juga memandang situasi dan kondisi. Adapun cara-cara yang dapat dilakukan seperti memberhentikan orang karena dicurigai oleh petugas baik sebagai pengguna maupun pengedar, menginterogasi di tempat dan melakukan penggeledahan, terbukti membawa barang bukti kemudian langsung, mencari tempat penjual minuman keras dengan membawa pelaku yang di curigai petugas, melakukan penggrebekan tempat jual beli minuman keras dan memeriksa izin edar, memberi peringatan kepada penjual dengan membuat surat pernyataan agar tidak mengulangi lagi.

Adapun Faktor pendorong dan penghambat diskresi kepolisian seperti yang telah dikemukakan sebelumnya, bahwa kewenangan diskresi kepolisian dimiliki oleh setiap anggota kepolisian pada saat menjalankan tugas dan fungsinya, sehingga hal ini menjadi faktor pendorong untuk dapat diterapkannya diskresi Kepolisian. Secara naluriah sebagai seorang aparat penegak hukum, seorang Polisi akan memiliki kepekaan dalam situasi dan kondisi tertentu untuk mengambil "tindakan lain". Namun, aturan hukum mengenai diskresi ini lebih bersifat umum dan sekedar memberikan kewenangan saja tidak diiikuti dengan petunjuk dan standar yang rinci dan jelas. Sampai sejauhmana penerapan kewenangan itu dapat

\footnotetext{
${ }^{20}$ Wawacara dengan Rudy Arto. Op.Cit
} 
dipertanggungjawabkan, merupakan suatu hal yang harus selalu diperhatikan. Hal inilah yang kemudian menyebabkan diskresi kepolisian dalam penyidikan menjadi sulit untuk dilakukan, karena menyebabkan polisi berada dalam posisi yang dilematis. Disatu sisi diskresi perlu dilaksanakan sebagai efisiensi dalam proses peradilan pidana namun disisi lain terbentur dengan kepentingan korban kejahatan itu sendiri. Maka dari itu rincian petunjuk dan standar yang jelas perlu diberikan agar kondisi-kondisi dilematis yang dihadapi oleh seorang Polisi pada saat akan mengambil langkah diskresi dapat diminimalisir. Rincian standar yang bisa diperjelas misalnya dengan melihat dari jenis/ sifat kejahatan dan pelanggaran yang dilakukan, status umur dan kesehatan dari pelaku kejahatan, rekam jejak kejahatan atas pelaku kejahatan yang bersangkutan serta derajat kerugian yang timbul dari kejahatan yang dilakukan (misalnya dengan menetapkan batas minimal). Dengan adanya petunjuk (guideline) yang lebih rinci, maka seorang polisi yang akan mengambil langkah diskresi yang dapat terukur dan dipertanggungjawabkan.

Tabel 2. Mekanisme Pelaksanaan Diskresi Dalam Penanganan Kasus Peredaran Minuman Keras Ilegal

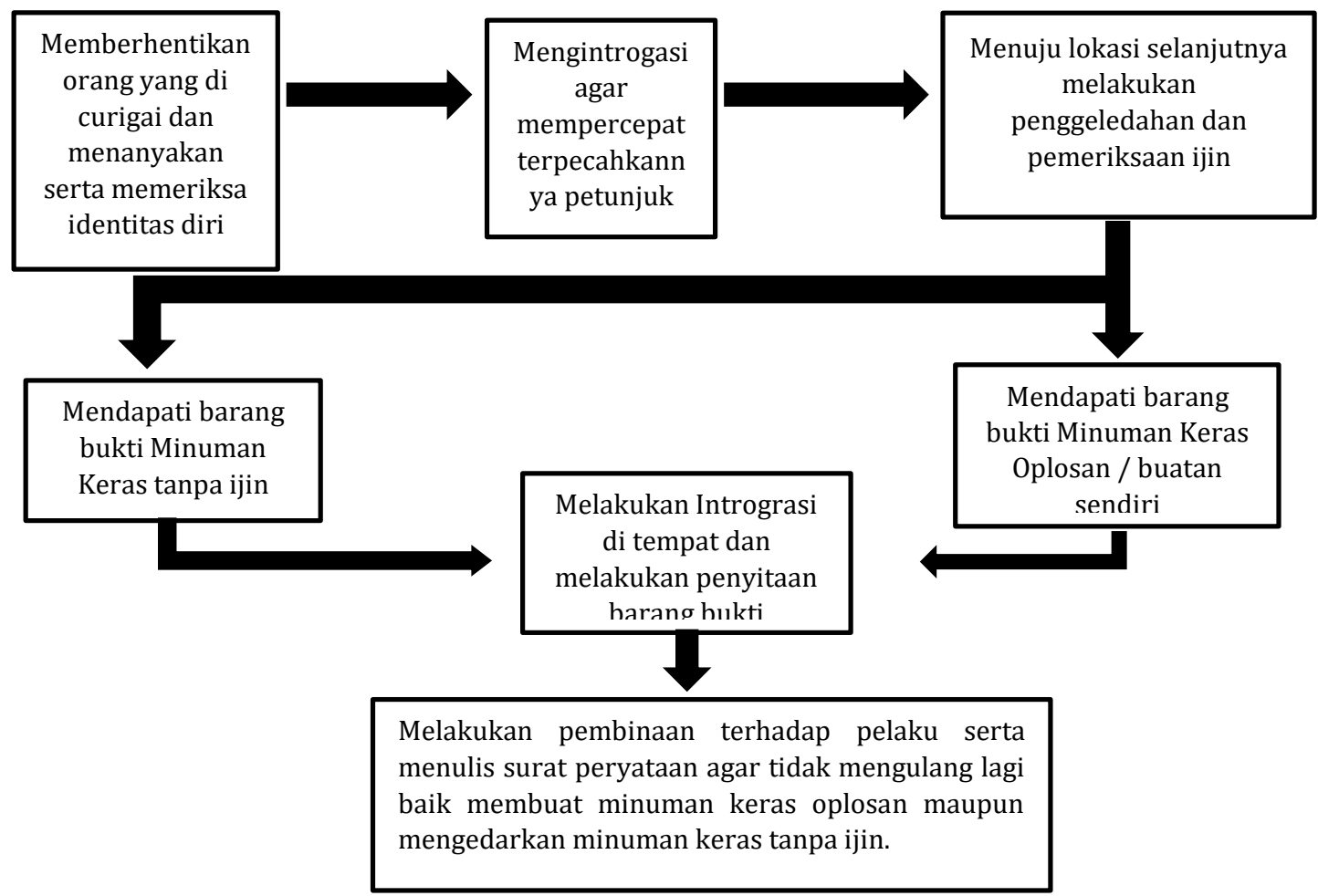

\section{Sumber : Rudy Arto Unit SATRESNARKOBA Polresta Yogyakarta}

Dalam sistem peradilan pidana, secara strategis tindakan diskresi ditentukan oleh polisi sebagai "the gate keeper of criminal justice system" yang menentukan masuknya kasus pidana dalam sistem peradilan. Melalui diskresi, suatu pengalihan bentuk penyelesaian dari penyelesaian yang bersifat proses pidana formal ke alternatif penyelesaian dalam bentuk lain diluar pidana dimungkinkan. Kata lain diskresi dianggap sebagai kebebasan kekuasaan untuk membuat suatu keputusan atas dasar kewenangan yang dimilikinya dengan memperhatikan kebaikan, pertimbangan pribadi dan keadilan bagi semua pihak, guna mencari alternatif lain yang bukan pidana. ${ }^{21}$

Letak diskresi oleh Polisi karena pada saat Polisi melakukan tindakan represif itulah timbul kebijaksanaan diskresi itu. Karena pada saat ada pelanggaran dan polisi menindak, lalu polisi dihadapkan pada dua pilihan apakah memproses sesuai dengan tugas kewajibannya sebagai penegak hukum pidana ataukah mengenyampingkan perkara pidana dalam arti melakukan tindakan diskresi. Tindakan

\footnotetext{
${ }^{21}$ Dermawan, Kemal. (2015). Sosiologi peradilan pidana, Jakarta: Buku Obor. h. 102
} 
Kepolisian yang berupa menindak (represif) yang kemudian dilanjutkan dengan tindakan diskresi ini, disebut dengan tindakan diskresi aktif. Sedangkan keputusan Kepolisian yang berupa sikap Kepolisian yang umumnya mentolerir (mendiamkan) suatu tindak pidana atau pelanggaran hukum disebut diskresi pasif. $^{22}$

Berdasarkan pembahasan diatas penulis menegaskan bahwa Diskresi Kepolisian ini memang diperlukan karena ruang lingkup aturan tidak dapat menjangkau secara detail setiap tindakan penyidik dalam menjalankan tugas, wewenang, dan tanggungjawab di lapangan sehingga perlu ada kebijakan dan pertimbangan subyektif dari seorang penyidik selaku aparat yang bersangkutan demi kelancaran tugastugasnya. Namun di sisi lain, dalam pelaksanaan diskresi dimungkinkan bisa disalahgunakan oleh oknum anggota di lapangan guna kepentingan pribadi berupa materi atau uang. Penyalahgunaan kewenangan ini justru akan menciderai keleluasaan polisi dalam melakukan diskresi yang mana sudah diberikan kewenangan diskresi namun malah disalahgunakan.

\section{Simpulan}

Berdasarkan hasil penelitian di atas bahwa diskresi dilakukan oleh Penyidik Polresta Yogyakarta dalam penanganan kasus peredaran minuman keras ilegal di Kota Yogyakarta dengan pertimbangan antara lain, denda terlalu ringan, kebiasaan suku tertentu, pelaku berusia dibawah umur/usia lanjut, faktor ekonomi, barang bukti tidak lengkap, untuk pengobatan atau jamu, efisiensi waktu, dan mencegah penumpukan perkara. Pertimbangan ini dilihat dari sisi kearifan personal masing-masing penyidik karena bersifat subyektif dan tergantung pada kasusnya itu sendiri, dapat mempersingkat waktu atau tidak. Sekalipun diskresi penyidik bersifat subyektif dan situasional, namun diskresi juga ada dasar hukumnya, sehingga tidak sembarangan.

Mekanisme pelaksanaan diskresi oleh Polresta Yogyakarta dalam penanganan kasus peredaran minuman keras ilegal di Kota Yogyakarta dilakukan dengan menyelidiki orang yang dicurigai petugas serta memeriksa tanda pengenal diri, menginterogasi, melakukan penggeledahan dan pemeriksaan izin, menyita barang bukti miras tanpa izin atau oplosan, dan melakukan pembinaan terhadap pelaku serta menulis surat peryataan agar tidak mengulang lagi baik membuat minuman keras oplosan maupun mengedarkan minuman keras tanpa izin.

\section{Daftar Pustaka.}

Buku

Abdussalam, H.R. (2009), Hukum Kepolisian Sebagai Hukum Positif dalam Disiplin Hukum. Jakarta: Restu Agung

Bakhri, S. (2010). Kebijakan Kriminal dalam Perspektif Pembaruan Sistem Peradilan Pidana Indonesia. Yogyakarta: Total Media.

Dermawan, K. (2015). Sosiologi Peradilan Pidana. Jakarta: Yayasan Obor Indonesia.

Faal, M. (1991). Penyaringan Perkara Pidana Oleh Polisi (Diskresi Kepolisian). Jakarta: PT Pradnya Paramita.

Fachmi. (2011). Kepastian Hukum Mengenai Putusan Batal Demi Hukum dalam Sistem Peradilan Pidana Indonesia. Jakarta: PT. Ghalia Indonesia Publishing.

Harahap, M.Y. (2016). Pembahasan Permasalahan Dan Penerapan KUHAP Penyidikan Dan Penuntutan. Jakarta: Sinar Grafika.

Puspa, Y.P, (1991), Kamus Hukum : Bahasa Belanda, Indonesia, Inggris. Semarang: Aneka

Rahardi, P. (2007). Hukum Kepolisian : Profesionalisme dan Reformasi Polri. Surabaya: Laksbang Mediatama.

\footnotetext{
${ }^{22}$ Wawacara dengan AKP Ahmat Djaeni Op.Cit
} 
Syamsuddin, A. (2011). Tindak Pidana Khusus. Jakarta: Sinar Grafika.

\section{Jurnal}

Rohadi \& Kusriyah, S. (2017). Peran Polisi Masyarakat (POLMAS) Dalam Menangani Perbuatan Akibat Minman Keras Di Wilayah hukum Polres. Jurnal Hukum Khaira Ummah, 12(3).

\section{Website}

Edi, Purnomo. (2019). 2 Penjual Ciu Di Yogya Ditangkap Usai 6 Orang Tewas Gara-Gara Miras Oplosan. Diakses pada tanggal 16 Februari 2020, https://www.merdeka.com/peristiwa/2-penjual-ciu-diyogya-ditangkap-usai-6-orang-tewas-gara-gara-miras-plosan.html

Edi, Purnomo. (2019). Gerebek Sebuah Ruko Di Yogyakarta, Polisi Amankan 2690 Botol Miras Ilegal. Diakses pada tanggal 16 Februari 2020, https://www.merdeka.com/peristiwa/gerebek-sebuahruko-di-yogyakarta-polisi-amankan-2690-botol-miras-ilegal.html 